OPEN ACCESS

Citation: Giulia Sandri, Felix-Christopher von Nostitz (2020) Party guests or party crashers? Non-members' political engagement across party organizations. Quaderni dell'Osservatorio elettorale - Italian Journal of Electoral Studies 83(2): 27-44. doi: 10.36253/qoe9712

Received: September 9, 2020

Accepted: December 18, 2020

Published: December 23, 2020

Copyright: (c) 2020 Giulia Sandri, FelixChristopher von Nostitz. This is an open access, peer-reviewed article published by Firenze University Press (http://www.fupress.com/qoe) and distributed under the terms of the Creative Commons Attribution License, which permits unrestricted use, distribution, and reproduction in any medium, provided the original author and source are credited.

Data Availability Statement: All relevant data are within the paper and its Supporting Information files.

Competing Interests: The Author(s) declare(s) no conflict of interest.

\section{Party guests or party crashers? Non-members' political engagement across party organizations}

\author{
Giulia SANDri ${ }^{1, *}$, Felix-Christopher von Nostitz ${ }^{2}$ \\ ${ }^{1}$ Université Catholique de Lille, France \\ ${ }^{2}$ Université Catholique de Lille, France \\ *Corresponding autor. E-mail: giulia.sandri@univ-catholille.fr
}

\begin{abstract}
Over the past decade, many parties have created new possibilities for affiliating and involving citizens, often rivalling the classic conception of party membership. So far, the existing literature has mainly focused on classifying these new and different types of affiliates. However, little attention has been paid to what these "non-fullmembership" options imply in terms of formal rights and obligations. We explore here the opportunities that parties offer to non-members to participate and get involved in intra-party activities and we contrast them with the rights and obligations of full, feepaying, traditional members. This article addresses this gap based on an original database consisting of membership rules in 68 parties in 13 established democracies. We not only map the current landscape of rules managing the involvement of non-members within parties, but also explore potential factors- party family and size- explaining the variation across parties. We find a strong association between party family and the range of possibilities for non-members' involvement with parties on the left and environmental parties providing more space for the participation of non-members. We also find that smaller parties tend to involve more non-full-members by allocating more rights to them. Our findings and new database provide a first step for future research to study the regulation of the involvement of non-members in intra-party activities, what determines it, and how it affects the traditional concept of party membership and societal linkage.
\end{abstract}

Keywords. Party politics, party membership, intra-party democracy, political participation, comparative politics.

\section{INTRODUCTION}

The continued progressive decline of electoral turnout and party membership in advanced democracies triggered a debate of the growing irrelevance and inability of parties to act as instruments for linking society with the state and aggregating preferences (Mair, 2013:16). In response, several parties have recently developed more flexible paths of political engagement outside elections (Scarrow 2015; Kosiara-Pedersen et al. 2017; Scarrow et al. 2017). They have adopted various organisational reforms to re-establish and strengthen their existing societal linkages by providing members with new rights and powers (Scarrow 2015; Pizzimenti et al. 2020). At the same time, 
parties moved beyond these classical ties by granting rights and powers to alternative forms of engagement such as supporters or primary voters (Poguntke et al. 2016; Webb et al. 2017; Gerbaudo 2019). Party elites now seem convinced that providing new forms of engagement beyond traditional party membership could help them not only to recruit volunteers, but also increase their financial resources and - in the end - preserve their membership (Sandri et al. 2015; Kölln 2016; Dommett 2020). Even though it is rather uncommon for supporters to pay much for being involved in party activities, and they pay markedly less than membership dues, they represent a way to encourage smaller donations and to collect significant amounts of funding during specific political events such as open primaries (Scarrow 2018; von Nostitz \& Sandri 2018) .

This new strategy of internal organization allows for a more flexible engagement with parties as it provides different channels of affiliation, each offering varying opportunities to access party activities and internal decision-making, adjusted to individual needs. Thus, it allows for wider societal linkage as it is able to include a more diverse society. For example, parties nowadays allow non-members to participate in electoral campaigns, policy development, leadership and candidate selection (Fisher et al. 2014; Kosiara-Pedersen et al. 2017; Gauja, 2014; Mjelde 2015; Aylott \& Bolin 2017; Ignazi 2020). Yet, despite the recent spread of these new typologies of participatory opportunities, further empirical research is needed to fully grasp what they actually entail in terms of instruments and possibilities for intraparty participation, rights and obligations. Moreover, the role and power of non-formalized forms of membership within political organizations still need to be empirically assessed, clarified, and compared to those of full members. This article aims at addressing this gap in the current literature by assessing the degree to which political parties allow for non-member participation in their activities.

The article distinguishes between two main channels of affiliation: registered party members (be them fee-paying, full members or "light" members) and nonmembers (i.e. citizens that have some form of flexible ties with the party, or any form of partisanship such as supporters, sympathizers or primary voters, but who are not registered formally as affiliates in any form). A formal registration requires a standardized application procedure, and an empirical form of approval of the acceptance of the request both by the prospective member and/or the party (eg: signature of a membership request form). Informal registration processes take the form of an oral or written informal request by the prospective member; or an online subscription by simply clicking on a button on the party website, or by entering the name and email of the prospective member on the party website. The article explores how these two forms of party activism are integrated and regulated in the formal party rules. The article then compares, and contrasts their respective rights and obligations, in order to assess their respective role and power within the party. These two main alternative affiliations represent two different organizational trajectories, one resulting in party membership, the other resulting in weaker, more flexible party ties.

This is relevant as it allows for apprehending the organizational transformations of contemporary political organizations. Further, these recent reforms challenges the traditional variation in terms of rights, obligations and forms of involvement among the different modes of partisan affiliation in established democracies and thus needs to be empirically documented and analysed. While the variation in membership forms within 'multi-speed membership parties' has been explored by a growing empirical literature (Scarrow 2015 \& 2020; Kosiara-Pedersen et al. 2017), the role, powers and activities of non-members within parties remain less clearly outlined by existing studies and needs to be comparatively and empirically assessed (Aylott \& Bolin 2017; Ignazi 2020; Scarrow 2020).

Further, recent studies have explored the attitudes and behaviours of new, non-formalized forms of adhering to a political party (notably Hooghe \& Kölln 2020 and Gomez and Ramiro 2019). However, most of these studies rely on survey data for measuring individual selfreported behaviours, rather than exploring the organizational role of such new innovative repertoires of political engagement and mostly focus on party or country case studies.

Thus, the authors created on an original comparative database exploring the formal regulation of rights, obligations, costs, recruitment procedures, and other variables measuring the organizational boundaries of parties for both party members and non-members in 13 established democracies in 2014. Change over time is not addressed in this article. For the moment, we focus on how the two different patterns of involvement are regulated and which powers they give to citizens, rather than looking at the extent to which non-members actually take advantage of the opportunities to participate.

The article starts by discussing the current state of the literature. After exploring these new forms of partisan mobilization in a descriptive manner, the article advances expectations about two possible factors that could explain the different degree of (non-) integration 
of new membership types: (1) party family, and (2) party size. Our exploratory findings show a strong association between party family and the degree of non-members' involvement, and that smaller parties tend to involve more non-members.

\section{EXPLORING HOW MEMBERS AND NON-MEMBERS CAN PARTICIPATE WITHIN PARTIES}

The recent literature often argues that the introduction of new forms of party affiliation, such as formalized supporters' networks, or of participatory opportunities for non-members, is a party organizational response to cope with such challenges as decreasing voter loyalty and declining party membership (Scarrow 2015). Other studies argue that these reforms make it possible to attract new sections of the electoral market, but do not guarantee loyal and consistent electoral support (Dalton and Wattenberg 2000; Cross and Katz 2013), thus negatively impacting upon the transformation of primary voters, supporters and "cyber-members" into affiliated members (Sandri et al. 2015). In this regard, party organization studies suggest that if parties aim at transforming new types of affiliates into full members, they need to make a choice between giving non-members many or few rights in comparison to full members (Scarrow et al. 2017). Giving new types of affiliates, and non-full members in particular, a broad range of rights could increase parties' societal reach overall, which is crucial for electoral politics, for strengthening the parties' social linkage role and for consolidating their legitimacy in an era of declining membership, even if they will never join as full members.

Conversely, allocating limited rights to new types of affiliates makes it possible to protect activists and to secure the recruitment of loyal full members, who are more likely to engage within the party (Kernell 2015). While openness in itself is unproblematic for the working of internal processes as long as members have little say over party decisions, if such a process is linked with membership empowerment and/or access to decisionmaking power that does not require any indication of organizational commitment (Bolleyer 2007), the inclusion of non-members with extensive rights can create tensions. In line with this argument, it is often argued that such reforms not only trigger potential conflict among traditional party delegates, activists and supporters (Cross and Katz 2013; Gauja 2013; Scarrow 2015), but challenge the role and powers of traditional affiliated members. These reforms also blur parties' organizational boundaries and the distinction between members and non-members (Katz and Mair 2009; Gauja 2014), challenging the notion of formal party membership (Gauja 2013; Scarrow 2015).

Several studies have explored empirically how parties manage affiliation (Kosiara-Pedersen et al. 2017; van Haute \& Gauja 2015; Bolleyer \& Correa 2020). Yet, further empirical research on the involvement of non-members is needed in order to explore the degree to which this trend could help parties to strengthen the representational linkage between citizens and the state. The article contributes to the current literature by measuring and comparing the actual rights allocated to full members and to non-members. Building on previous research (Scarrow 2015; Kosiara-Pedersen et al. 2017; Gauja and van Haute 2014), we explore the regulatory instruments for involving non-members within parties and the extent to which traditional members are protected by party structures in terms of obligations, specific rights, and degree of permeability. The contribution of our article to the literature is both empirical, because we develop further and go beyond previous theoretical analyses (Gauja, 2014; Mjelde 2015), and in terms of analytical model, given that, contrary to previous empirical studies (Kosiara-Pedersen et al. 2017), we focus specifically on the intra-party engagement rules for non-members.

The growing literature on new forms of party affiliations has raised the relevant question of the potential individual and meso- level consequences of parties' strategies to reach out to broader groups of potential supporters offering them new affiliation options (Kosiara-Pedersen et al. 2017). Previous studies have also raised the question of which role should parties give to traditional party members and to new affiliates within these innovative organizational settings, in particular in terms of party ownership (Scarrow 2015).

In particular, this article's results relate to studies with similar questions and operationalisations of variables in two ways. First, if compared to Scarrow's multi-speed membership concept and research (2015), the article contributes to the literature by looking specifically at non-membership possibilities to get involved in parties, rather than mapping the universe of different types of affiliation. Moreover, different from Scarrow, we not only look at affiliation categories, but also empirically assess the regulations, obligations and rights associated to each one of such categories. In addition, we relate the degree of organizational accessibility of membership types with the powers allocated to each of them. Second, different from the studies using the PPDB project's data (Poguntke et al. 2016; Kosiara-Pedersen et al. 2017), our analytical perspective focuses on the individual point of view of potential members and non- 
members, to explore the channels through which they can get involved within the party, and the financial costs they have to face and the accessibility rules of the different (members and non full members) affilation modes, rather than the party itself. Moreover, the works based on the PPDB data only identify the existence of alternative types of affiliations, but the operationalization of the variables does not allow distinguishing clearly how many and what types of options for affilating with the party beyond formal mebership exist. When assessing who is deciding upon program, candidate selection, etc., the PPDB lists how non-members are included, nonetheless a further clarification among the different modes for being involved still needs to be developed.

Hence, while the PPDB dataset allows measuring whether there are other types of party affiliations than full membership and how non-members may influence party decision-making, it does not offer detailed information on what type of alternative affiliations are offered, how many, how they are regulated and what rights and obligations the different kinds of non-members have. The PPDB dataset provides this information for full membership categories, and describes the rights of non-members to participate in some decision-making processes, but without clearly formalizing and distinguishing the various non-member categories. In contrast, Scarrow provides a detailed overview of the universe of party affiliations, including full membership, offered on the party websites. Her seminal study also assesses how easy it is to enrol in parties online (i.e. the accessibility index). However, her data does not develop further how parties regulate these different types of affiliations in terms of both rights and obligations. Further research is needed in order to assess what non-members can do exactly within a party and at what cost and how this compares to full members. Therefore, this study aims at bridging the small but important empirical gaps remaining in these two sets of previous studies (the PPDB based ones and Scarrow's) by focusing on comparison of the powers allocated to members and non-members. As party rules, party websites and affiliation types offered change overtime, we needed to collect data measuring these main dimensions of analysis at the same time, and thus we had to resort to a new, separate data collection.

We consider that involved non-members are voters/party identifiers that are not necessarily interested in becoming full members, but who voluntarily connect with a party, who want to participate in specific internal events (online or physical; open to the public or closed to registered participants) and are thus willing to register as a party "friend", "supporter", "cyber/guest member" or "sympathizer" (Kosiara-Pedersen et al. 2017). In order to do so we explore four main dimensions analysing party organizational settings and regulatory differences.

The main dimension of analysis captures the modes of partisan affiliation as a member or non-member offered by parties and their costs. This is particularly relevant from an individual perspective given our research question, as individuals willing to connect with a party have two options: joining as a full member or through nonmembers. The choice is primarily based on a cost-benefit analysis of each status from the supply side of party membership (Heidar 2006; Kosiara-Pedersen et al. 2017). Citizens will enroll as full members only if they consider that the benefits of full membership outweigh its cost and obligations. This dimension comprehends two subdimensions based on the sets of rights and obligations regulating the two membership types, measuring:

(a) How organizationally permeable are parties, especially in terms of barriers for joining (Scarrow 1996: 17). The lower the barriers, the broader is the party's societal reach. This is measured on a spectrum that goes from parties that consider all who attend a party event or donate to be party members, to party rules entailing the regular payment of inscription fees, exclusivity and other formal procedures for joining. This is relevant because with full organizational permeability the status of non-members and of members would be identical, even though this does not mean that different groups share the same rights. As long as parties offer both forms of affiliation, there may be a substantial difference in obligations and rights attached to them.

(b) The balance of power of members vs. non-members, measuring the range of the requirements imposed and privileges distributed to the different categories of partisan affiliation (Pedersen, 2003: 39). In particular, it captures the degree of formal involvement of non-members, meaning the statutory mentions of what non-members are permitted to do. We look at the distribution of power within parties by accounting for the activities or privileges traditionally reserved for members that are also offered to all the other categories of partisan affiliation (Gauja and Van Haute 2014). This is not about real participation/involvement but formal opportunities to get involved.

Specifically, we outline the extent to which nonmembers can participate in and are formally integrated within the party. Furthermore, we discuss the implications of adopting these new forms of engagement. Ultimately, we show that rather than substituting the existing conception of party membership, the non-members complement it as new and smaller parties can gain supporters and all parties can recruit more resources in times -such as elections for example- when they need 
them more without challenging (and risking losing) their traditional grass-roots. Further, our study adds to the understanding of party membership by focusing on the empirical assessment of both the regulation of new affiliation categories and of non-member participation within parties, rather than simply exploring how parties manage affiliation as done by previous studies.

We further argue that the parties' choice to increase linkage options is affected by their organizational (and specifically their size) and party family features. The choice of party-level (demand side) explanatory factors to explore potential features underlying cross-party variation is supported by a growing number of studies that have recently applied an organizational perspective to the study of the main determinants of party membership (Gauja and van Haute 2015, van Haute 2016; Scarrow et al. 2017; Kölln 2016; Weldon 2006). Based on the literature on party politics, intra-party democracy (IPD) and political membership (for a review, see van Haute, 2016), we identified two main factors that could explain the variation in the types of partisan affiliations and in their respective degree of involvement within the party: party size and party family.

Regarding party size, our theoretical standpoint is Michels' classic argument ([1911] 1962) that larger parties require more complex organizational structures, triggering the deterioration of IPD and opportunities for internal mobilization. More recent empirical studies have shown, however, that organizational complexity, usually associated with party size, gives members greater opportunities to participate in the political processes (Scarrow 2000). Some studies argue that more members are active when more elaborate organizational structures of large parties provide additional opportunities for participation (Scarrow 2000: 95). This could also suggest that organizational complexity may increase the chances of involving also non-members in party activities. However, the larger the party, the more it benefits from already broad legitimacy, social linkages and grassroots resources. Thus, larger parties have fewer pressures to adopt new affiliation categories and to give new affiliates extensive rights, and tend to protect existing full members to a greater degree (Scarrow 2000).

Small parties, on the contrary, need more volunteers for running effective campaigns, for increasing their legitimacy and for broadening their societal linkages. So, by providing channels for participation also for nonmembers, and by endowing them with extensive rights, small parties aim to attract supporters and then mobilize them when needed.

This rationale of capturing variation of the possible involvement of non-members within parties pro- vides our dependent variable. In contrast, other less recent empirical and theoretical literature shows that smaller parties tend to involve their members more (Tan 1998; Weldon 2006). By extension, smaller parties are also more likely to involve non-members in order to strengthen their base and broaden their organizational reach. Larger mass-based parties tend to rely on more complex organizational structures and to give more power and individual rights to their enrolled members. By doing so, larger parties incentivize their participation. On the contrary, smaller parties are more likely to be organizationally open in order to compensate for their modest size (especially during electoral campaigns) and thus to allocate more rights to non-members (Faucher 2015; Scarrow 2015; Garland 2016). They are less interested in having a broad grassroots base of activists and aim rather at reaching out to a wider range of individual supporters. Following this logic, we argue that smaller parties are characterized by a higher degree of involvement of non-members. As this is an exploratory study, we do not formulate proper, verifiable hypotheses, but expectations that are rather more general:

Expectation no. 1: The smaller the size of parties, the greater statutory participation rights for non-members.

Second, party family might contribute to explaining the variation in the degree of involvement of nonmembers and the extent of rights and obligations distributed to them. The literature often argues that parties situated at the two extremes of the right-left spectrum are generally characterized either by complex structures for securing high membership participation (left) or by strongly hierarchical organizations (right) (Kitschelt 2000). Bolleyer (2007) hypothesizes that new parties on the left embrace societal individualization processes fully and incorporate them organizationally, weakening their organizational boundaries. Thus, we expect party family to constitute relevant factors explaining how parties link to civil society. Thus we expect parties belonging to social-democratic/leftist families to be characterized by a higher degree of involvement of non-members.

In terms of party family previous literature supports the relationship between party family and intra-party democracy (IPD) (Gibson and Harmel 1998; Bolin et al. 2017, Von dem Berge and Poguntke 2017). Leftist and social-democratic parties are traditionally more open to broadening their base, thanks to their experience with associated membership (trade unions) and the fact that they need to rely more on mass funding rather than a few wealthy donors (Garland 2016). Thus, different party families with its diverse organisational traditions should also affect the role and relationship of members, non- 
members and their inclusion into the party organisation.

Moreover, in order to identify our main explanatory factors, we build not only on the above-mentioned main theories of party organization, but also develop further some theoretical implications raised but not fully assessed by PPDB based research. The latter (KosiaraPedersen et al. 2017 and Scarrow 2015) has shown that there is a huge variation in the degree of accessibility across parties and countries and that this variation is higher than the variation of regulation of different types of affiliation (multi-speed index). So, we assess the association between the range of affiliation forms offered by parties and party families, but we also go beyond this by looking at the relationship between rights and obligations of each affiliation category and party styles or organizational tradition (measured by a proxy, party size). We thus try to explain variation in party organizational trajectories by party size and not only by county and party family. We thus contribute to the ongoing debate about party accessibility, type of affiliation and party organizational traditions by assessing to what extent party size could explain parties' strategies concerning their membership boundaries. As Scarrow suggests, organizational styles and "traditions might constrain experiments with new types of affiliation options: parties which view members primarily as fans should be least concerned to police the boundaries of membership, while those which view members as part of a cleavage community, or of an ideological movement, might be more likely to preserve control over admission to the party" (2014: 20).

Expectation no. 2: Parties belonging to centre-left party families will allow for more involvement of nonmembers than parties belonging to centre-right and other party families.

Our aim is more exploratory than explanatory; thus we mostly explore correlations among variables rather than establish causal links. The article primarily contributes to our understanding of what the party base is and the exploration of parties' degree of openness to nonmembers makes it possible to evaluate how they interact with their voters and with society.

\section{DATA AND METHODS}

We decided to collect a small-N empirical dataset. It consists of 68 parties in 13 stable parliamentary democracies $^{1}$ where (at least some) parties use different modes

\footnotetext{
${ }^{1}$ Austria, Belgium, France, Germany, Ireland, Italy, Portugal, Spain, UK, Switzerland, Canada, Australia, New Zealand.
}

of partisan affiliation and direct democracy (such as primary elections). The dataset is mainly based on publicly available material from the parties' websites and statutes. This captures how parties formally presents its affiliation options to the public and how they organize on paper, which of course in reality and daily practice might diverge from this formal regulation. In order to analyse the regulation of members and non-members across parties in different political settings the dataset covers both democracies in the European Union (EU) and non-EU European democracies but also Commonwealth countries. We also include France, now a semi-presidential system, but its party traditions formed during the country's era as a parliamentary democracy. One of the central reason to focus on these cases are their shared political tradition, experiences and influence on each other leading to similar views on how parties should organise in general and in relation to its members and supporters more specifically (Scarrow 2015: 7-8).

The second reason is that parties in these countries are strongly affected by the current membership decline and thus at the forefront to develop new strategies and approaches to address this development (Scarrow 2015; van Biezen et al. 2012). Lastly, the similarity of the cases and the general comparability of their political systems reduce the contextual variation in order to develop the analysis ceteris paribus. Still the cases provides variations in key features such as electoral system, party system, form of government, concentration of executive powers vs power sharing, etc. that which have been linked to party organizational development and role of party membership. These and the range of organizational differences present in our main unit of analysis, the individual party (including parties with no or limited IPD), provides the theoretical variation of our main independent variables (party size and family) needed for assessing its impact on non-member participation. We limit our study to parliamentary parties that have either obtained at least $5 \%^{2}$ of votes in the last elections or have coalition or blackmail potential (mainly new right-wing populist parties such as FN, UKIP, AfD or BZÖ; see Appendix A for full list of cases). Thus, while our findings relevance are limited to the cases analysed here, our cases represent and exemplify the diversity that exists across parties and thus our case selection is likely, compared to a selection of more homogenous set of countries, to be representative

\footnotetext{
2 The choice of this criterion is based on the fact that the legal threshold of $5 \%$ of votes casts is the highest and most used threshold in the rules for national parliamentary and EU elections in EU members states (e.g. is used by Germany, Belgium - by constituency- , France - for EU elections-, etc.). See for instance: https://www.venice.coe.int/webforms/ documents/?pdf=CDL-PI(2018)004-e
} 
in the minimal sense of representing the full variation of the population. It therefore allows conducting explorative research that is also relevant for parties operating in other countries not covered here.

Our dataset differs from previous studies (KosiaraPedersen et al. 2017, and particularly the PPDB project dataset, see Poguntke et al. 2016 and Scarrow et al. 2017). Our dataset integrates a broader set of indicators for measuring non-member participation by analyzing party statutes and websites. The inclusion of websites is also important as nowadays they are often the first point of contact and parties can make it easier to join as either member or non-member or to become active by providing for online participation (online voting, members' area/forums, etc.).

More specifically, we look at both party statutes (i.e. internal formal rules) and their websites (i.e. the public face of the party) per each selected case at the same point in time. More specifically, we assess how these two sources of information present and regulate the different modes of interaction with the party for members and non-members. These two sources combined also allow assessing the degree of difficulty to become active within the party (i.e. individual effort or cost). Thus, the article - like past studies - looks at statutory regulation, but also at party websites as the first and main point of interaction between parties and actual and potential members.

As explained above (see section 2), the PPDB study could be enlarged by looking not only at rights and obligations generally allocated to alternative affiliation categories, but also at the regulation of specific types of nonformalized membership and at the powers allocated to each of them, compared and contrasted to those allocated to full members. This would make a significant difference in the analysis of the dynamics of political activism since it allows measuring more effectively the degree of openness of party organizational boundaries and its consequences. This allows exploring more in depth the different strategies of contemporary parties: are they more interested in boosting their enrolment numbers by providing less costly full membership or are they aiming at mobilizing new activists, even though they are not formally enrolled? Are they distributing rights to both full members and non-members to increase engagement at any cost or are they keeping some privileges only for full members as to maintain a smaller but more loyal base?

Moreover, while we focus on a small $\mathrm{N}$ sample of parties, within each country case we cover more parties than the PPDB Round 1 (see France for example) and we use similar indicators as Scarrow (2015) but collect more recent data (Scarrow's data captures the situation in 2011). We also develop further indexes that comple- ment Scarrow's accessibility index and multi-speed indexes. Overall, this article offers a more fine-grained dataset with a specific focus on both members and nonmembers possible activities within parties, in particular if compared to the operationalization of the variables in the PPDB. The latter uses mainly one item to measure other types of affiliations (at least according to the codebook, see Poguntke 2016): the item "CR7FRIEND", which assess whether the party statutes recognize a separate level of formal affiliation with reduced obligations and reduced rights (for instance, party "friend" or "registered sympathizer"). This item does not include members with reduced dues but full rights, such as reduced fees for young people or unemployed citizens. Therefore, in the PPDB, alternative affiliation is a dichotomous variable coded 0 if the party allows only formal membership, and 1 if the party also offers an alternative affiliation option (Kosiara-Pedersen et al. 2017).

The limited geographical reach of our small-N sample ensures that concepts such as IPD and membership are understood in a similar way and allows for meaningful comparison. Our main data source was the most upto-date parties' statutes, provided online or by the party, as well as their websites for further information such as membership fees or the possibility of non-affiliated participation options.

\subsection{Operationalization of the dependent variables}

Next we provide the main indicators and their operationalization measuring party organizational settings:

1. Types of affiliation and non-formalized membership: following previous studies (in particular Scarrow 2015 and Kosiara-Pedersen et al. 2017), we account for six categories of partisan affiliation based of the degree of formality and their cost (fees): Full formal members, (registered) Supporters, Financial supporters, Trial members ${ }^{3}$, Registered primary voters, and Non-affiliated participants/volunteers. They are coded as dichotomous variables and merged into an additive index. All parties provide the option of formal, full, direct membership. The higher the score, the more different possibilities for getting involved with the party exist.

We also coded the price for each of these affiliation categories by using the average annual fee level (in Euros). The inclusion of price of affiliations is vital as it determines the cost of participation and can be instrumental in increasing certain types of party affiliation

\footnotetext{
${ }^{3}$ Trial Members: informal membership with the formal possibility and individual intention of becoming full member.
} 
or discourage them. Thus, it can increase participation in primaries or encourage people to join as supporters or members depending on the cost-benefit analysis of cost of participation and rights gains. Further, different costs of engaging with parties can allow for inclusion of broader shares of society in party activities and thus can be used to improve societal linkage. In short, affiliation cost plays a major role in determining who participates, in what activities and at what point in time. Some parties even use progressive income dependent membership fee scales or a percentage of the income rather than absolute numbers ${ }^{4}$. Therefore, we calculated the average fee (highest-lowest fee possible/2).

2. The degree of organizational permeability for fullmembership: this scale is based on indicators measuring membership accessibility, its formality- signature, visit to party office or online-and the degree of complexity of recruitment procedures 5 . We recoded the data following the path of least resistance. Thus, if members can sign up both online or in person with a signature we recoded only the former. Further entry barriers considered are: minimum age requirements ${ }^{6}$, the body responsible for selecting the new members, sponsorship by existing member(s), membership incompatibility rules, and disciplinary procedures for disrespecting the requirements or violating party rules 7 , all coded dichotomously. The fees are re-coded as either below average $(=0)$ and above average $(=1)$. Combined costs and barriers to entry indicators provide one single index measuring the level of organizational permeability. The final index is a simple additive scale of the score of each party on each category (Cronbach's alpha: 0.43), from 0 to 8 .

3. Rights and obligations allocated to full-members: these variables are measured through two cumulative

\footnotetext{
${ }^{4}$ This is mainly case for full membership fees. For example, the German Greens charge consists in $1 \%$ of annual income after taxes. We have calculated it by using the average household net-adjusted disposable income per capita in Germany (data provided by the OECD: http:// www.oecdbetterlifeindex.org/topics/income/ )

${ }^{5}$ In Switzerland, it is the cantonal party organization that regulates the entry requirements. We used the regulation of Bern and Zurich to code these regulations as they are - in terms of population- the biggest cantons and thus their rules apply to most party members. Also in Australia membership fees are set by the State party branches (we calculated average values where possible). In some cases, membership fees are set by regional and not national party bodies (for example in Austria). In this case, we calculated the average price of party membership.

${ }^{6}$ Some parties set a minimum age, but this minimum is below voting age (usually to be over 16 years old). We still consider it as a barrier to entry.

${ }^{7}$ The provision of disciplinary procedures is here seen as something positive as it allows rejected applicants to challenge the rejection or expulsion and requires the deciding body to justify it ruling.
}

indexes of obligations imposed ( 0 to 4 ) and privileges distributed (0 to 8) to formal members (Cronbach's alpha: 0.26 and 0.77 ). The higher the individual score, the more extensive rights and/or more obligations fullmembers have. We look at the following rights: right to stand as candidate for elected office, ${ }^{8}$ to attend the party congress without being delegate, to vote at the party congress, to call the party congress, to select the party national executive organ, to select parliamentary candidates $^{9}$, to select presidential or prime ministerial (or, generally, chief-executive) candidates, and to select the party leader. ${ }^{10}$ We explored the following obligations: to pay an inscription fee; to go through a probation phase, to adhere to party rules/principles; and to be involved regularly in party activities (Cronbach's alpha: 0.26 ).

4. The degree of formal involvement of non-members this variable focuses on the participatory privileges (and potential obligations) of non-members. The rights of non-members cumulative index ranges from 0 (no rights) to 7 (all possible rights). The index includes the following indicators: non-member right to participate in party activities in general (canvassing, campaigning, rallies, attending local party meetings/events, etc.); right to attend the party congress; right of voting in internal votes (at all levels); right to stand as candidate for elected office; right to select parliamentary candidates; right to select presidential/PM/chief-executive candidates; right to select the party leader. While in some of these activities non-member can always engage spontaneously, many parties nowadays provide official possibilities to sign up to for example to help with campaigning and thus create a more formal link with non-members. Here, in addition to the rights listed in the statutes, we coded these official offers as specific rights of non-members.

\subsection{Operationalization of the independent and explanatory variables}

We have selected two independent variables that could explain variation in membership categories and the rights/obligations of members vs. non-members: party family and party organizational type.

\footnotetext{
${ }^{8}$ This is coded as "yes" if the party statutes clearly state the right of all members to be candidate and candidacy does not require any further requirements.

${ }^{9}$ Here too, we recoded the data following the path of least resistance. Some parties allow members only to approve the final list, others grant them the right to amend the proposed list, and others let members intervene at all stages of the process. We decided to look at whether members are formally involved in at least one stage of the process.

${ }^{10}$ All rights and obligations were coded 1 when stated in party rules or
} websites and 0 when non-existent. 
1. Party family: for coding party family, we use the classifications of the Comparative Manifesto Project based on right-left positions ("rile scores"). We divided the cases into two broad categories of left and non-left party family groups. The former includes ecological, social democratic and socialist parties while the non-left consists of liberal, Christian democratic, conservative and nationalist parties. For some cases, such as special/ one-issue parties, agrarian or ethnic and regional parties, the classification is more challenging and the article used the proximity of the rile score to the parties grouped as left or non-left in order to classify them correctly. The CMP date set included all parties coved in the article.

Our dataset consists of 33 (45.8\%) left and 37 (51.4\%) non-left parties. The use of similar classifications of party families in the latest party politics literature (Pilet and Cross 2014 and 2015; Van Haute and Gauja 2015; Pettitt 2014. Poguntke et al. 2016) points to the fact that such classifications provide a good proxy for ideological orientation (and party styles and organizational traditions), which gives a good indication of the party's general attitude towards members, including their roles, rights and obligations within the party and thus are appropriate in assessing our expectations. We also unpack the differences between party families further by outlining how they differ in terms of organizational permeability, rights and obligations of members and non-members.

2. Party Size: in order to measure party size and its effect on the involvement of non-members, we use the pertinent proxy of $\mathrm{M} / \mathrm{E}$ ratio based on aggregate membership size to calculate the relative size of each individual party's grassroots base with regard to the overall electorate ${ }^{11}$. We classified the $\mathrm{M} / \mathrm{E}$ ratios - based on each countries mean values for the $\mathrm{M} / \mathrm{E}$ ratios $^{12}$ - using three distinct cut-off-points: small, medium-sized or large membership party. Consequently, for instance, the Australian Labour and Irish Fianna Fail are classified as large, the Austrian Swiss SPS/PSS or Belgium CDH are classified as medium, and the BZÖ or the German AfD are classified as small. Table 1 outlines the classification of parties according to size (per country):

\footnotetext{
${ }^{11}$ It is possible that party rules about non-member rights could affect the proportion of voters who choose to become members; if so, the M/E ratio is not independent from the rules themselves. Using vote share to assess party size would avoid this problem. However, we decided to keep $\mathrm{M} / \mathrm{E}$ as measure of party size because it is the main indicator used in the literature on membership and party organizations (van Haute and Gauja 2015).

${ }^{12}$ Cut-off points: (1): E/M Score more than 0.5 points $<$ the national mean of $\mathrm{M} / \mathrm{E}$ ratio = small party; (2) $\mathrm{E} / \mathrm{M}$ Score less than 0.5 points $<$ the national mean of $\mathrm{M} / \mathrm{E}$ ratio= medium-sized party (3) $\mathrm{E} / \mathrm{M}$ Score $>$ the national mean of $\mathrm{M} / \mathrm{E}$ ratio = large party.
}

Table 1. Party size.

\begin{tabular}{lcccc}
\hline & Small party & $\begin{array}{c}\text { Medium- } \\
\text { sized party }\end{array}$ & Large party & Total(N) \\
\hline Australia & 0 & 2 & 3 & 5 \\
Austria & 3 & 0 & 2 & 5 \\
Belgium & 2 & 3 & 4 & 9 \\
Canada & 2 & 2 & 1 & 5 \\
France & 1 & 2 & 2 & 5 \\
Germany & 7 & 0 & 0 & 7 \\
Ireland & 0 & 2 & 2 & 4 \\
Italy & 2 & 2 & 3 & 7 \\
New Zealand & 1 & 2 & 1 & 4 \\
Portugal & 0 & 2 & 2 & 4 \\
Spain & 1 & 1 & 2 & 4 \\
Switzerland & 1 & 1 & 3 & 5 \\
UK & 1 & 1 & 2 & 4 \\
Total(N) & 21 & 20 & 27 & 68 \\
\hline
\end{tabular}

\section{NON-MEMBERS' CHANNELS FOR PARTICIPATION WITHIN POLITICAL PARTIES}

In the following section, we discuss the collected data by presenting our general findings and then we assess our two expectations linking the relationship between party size and family on the scope of intraparty participation opportunities for non-members. It is important to point out that the statistical significance of our analysis is limited by the small number of cases in the database.

First, we present a few descriptive accounts of our data. Table 2 offers an overview of the average, minimum and maximum prices for each category of party affiliation, for both members and non-members.

While in German and French parties full membership costs are much higher than in most other countries, in Belgium and Spain they are very low. In for example the Australian Pirate party, as well as the M5S and SEL

Table 2. Price of full membership and non-membership types of affiliation.

\begin{tabular}{lccccc}
\hline & $\mathrm{N}$ & $\begin{array}{c}\text { Mini- } \\
\text { mum }\end{array}$ & $\begin{array}{c}\text { Maxi- } \\
\text { mum }\end{array}$ & Mean S.D. \\
\hline Price of Standard Membership & 66 & 0 & 330 & 41.7 & 62.5 \\
Price of Supporter Status & 36 & 0 & 250 & 11.5 & 43.1 \\
Price of Financial Supporter & 19 & 4 & 3955 & 325.2 & 923.8 \\
Price of Trial Membership & 3 & 0 & 30 & 10 & 17.3 \\
Price of Primary Voter & 14 & 0 & 2 & 0.5 & 0.85 \\
\hline
\end{tabular}

Note: Total $\mathrm{N}=68$ parties. 


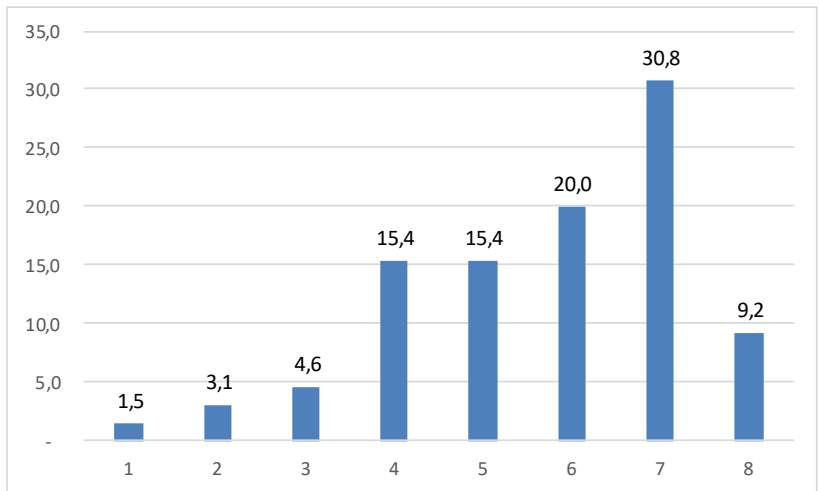

Figure 1. Organizational permeability index (\%). Note: Total $\mathrm{N}=68$ parties.

in Italy, full members can join by contributing a voluntary donation. The party affiliation as a "supporter" is mostly free (e.g. for the German, Australian or Austrian Greens) or very inexpensive (e.g. for the UK Labour and Tories). However, for the Irish Fianna Fail, joining as a supporter is actually more expensive than as a full party member, with the former costing 75 euros and the latter 50 euros.

If we look now at the degree of organizational permeability, Figure 1 shows that the lower the score, the more permeable the party is for full members. The less "open" parties in our database are right of center parties such as the Belgian NVA, Austrian ÖVP or the Swiss UDC. The more permeable ones, besides US parties, are usually Greens and new left/populist parties (e.g. Podemos and M5S). For most parties in Westminster democracies, entry barriers are very low and citizens can join by simply enrolling online. In contrast, the German Greens require the local party unit to decide to accept new members. Many parties, including the British UKIP as well as the Italian LN and SPD, impose a probation phase for new members, and the Spanish PP requires sponsorship by an existing full member to join.

Figure 2 offers insight on the rights and obligations allocated to full-members: Most parties provide members with rights in three areas. Further, there seems to be a polarization of the sample along this indicator: equally large shares of parties either provide no rights at all or a very high number of rights. If almost half of the sample allows full members to stand as candidates for elected office without any additional requirement or to attend the party congress as observers, only a few parties allow them voting rights at the congress. Almost $1 / 4$ of the selected parties involve full members in the selection of the executive body, while $47.2 \%$ allow for participation in leadership, $62 \%$ in parliamentary, and $51 \%$ in chief-executive candidate selections.

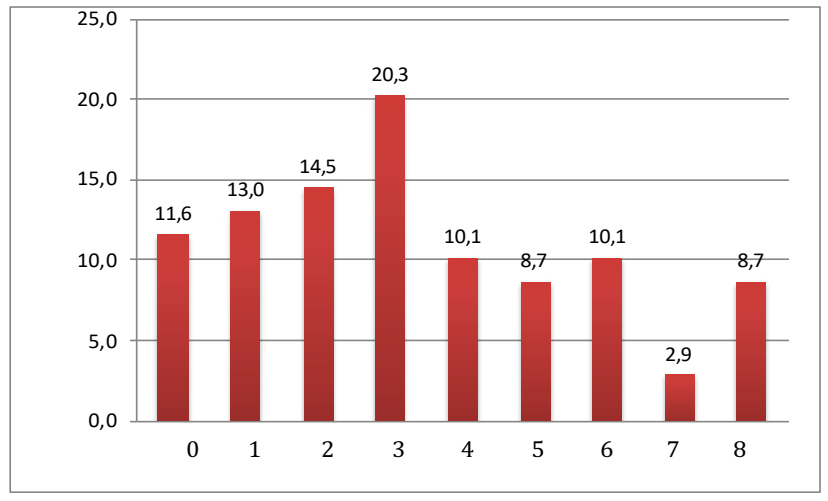

Figure 2. Membership rights index (\%). Note: Total N=68 parties.

Figure 3 shows that most parties impose quite extensive obligations with a score of two or three. While only a few parties require a probation phase (e.g. Belgian and some far right parties), $77.8 \%$ still require members to respect party principles and positions, and $30 \%$ require members to actively participate regularly in party activities. Most impose annual membership and membership incompatibility rules.

Figure 4 shows the parties' distribution along the non-members participation index (Cronbach's alpha: 0.64). No party actually achieves the maximum score of 7. Only five parties -mainly left and green parties with candidate and/or leadership primaries- grant rights in five or more areas to non-members, while the majority grants only one right, primarily to formally attend party meetings (local or national level) and/or participate in electoral campaign activities. Right or populist parties (e.g. the French FN or the Portuguese CDS-PP) do not allow any form of involvement by non-full members. The remarkable exception to the above is the Flemish green party, Groen, which grants extensive powers to full members but none whatsoever to supporters and voters.

Figure 5 shows the distribution of the selected parties per different types of party affiliations offered according to their formal rules. Unsurprisingly, all par-

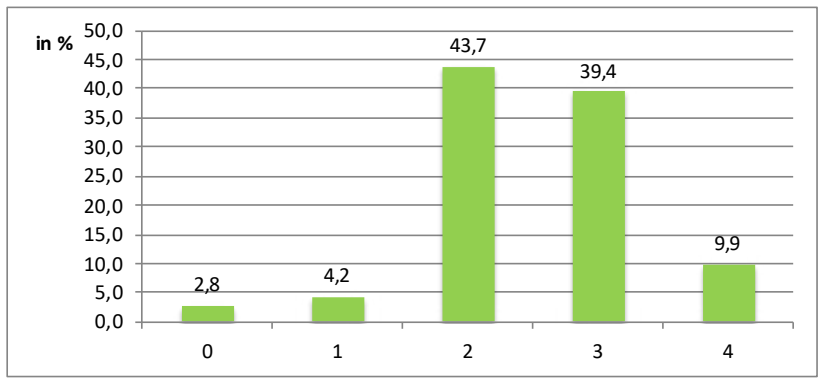

Figure 3. Membership obligations index. Note: Total N=68 parties. 


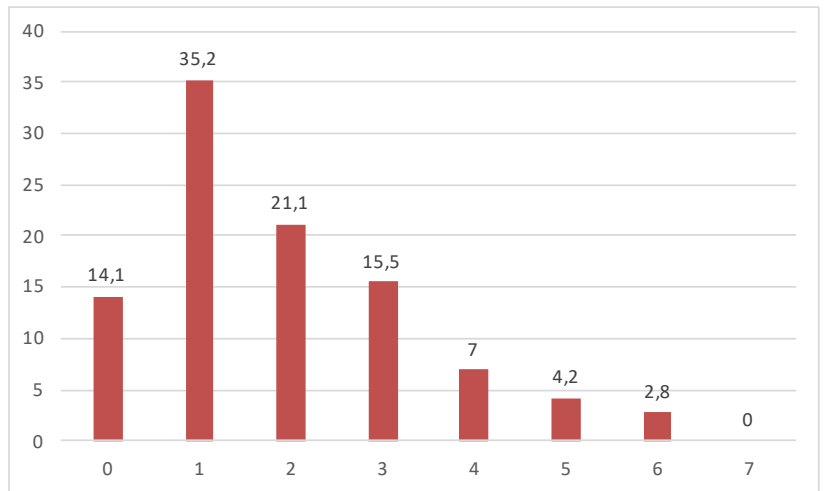

Figure 4. Non-members' participation index (\%). Note: Total $\mathrm{N}=68$ parties.

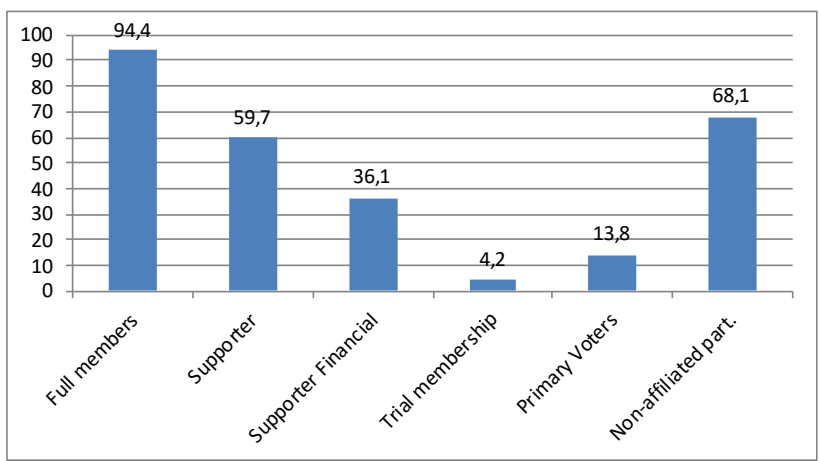

Figure 5. Variation in the types of affiliation (\%). Note: Total $\mathrm{N}=68$ parties.

ties offer full membership. More interestingly, almost $60 \%$ of the sampled parties also offer the possibility to join as a party "supporter" and even more parties (68\%) allow for some forms of non-affiliated participation. However, only 10 parties in the sample use open primaries to involve voters and supporters in their internal decision-making.

Figure 6 provides insight into how many different types of party affiliation beyond full membership parties can provide according to their internal regulations. As Figure 6 shows, the maximum score is three (e.g. the French PS) and no party in our sample allows for more than three different types of non-member affiliation in addition to full membership. While for instance in all four New Zealand parties people can choose between two different types, the Swiss BDP/PBD and French FN only offer one type of non-member affiliation, as (financial) supporter. We can see that most parties (58.3\%) provide either one or two types of affiliations beside full membership. Combining this with the findings presented above (Figure 5), we can assume that most other

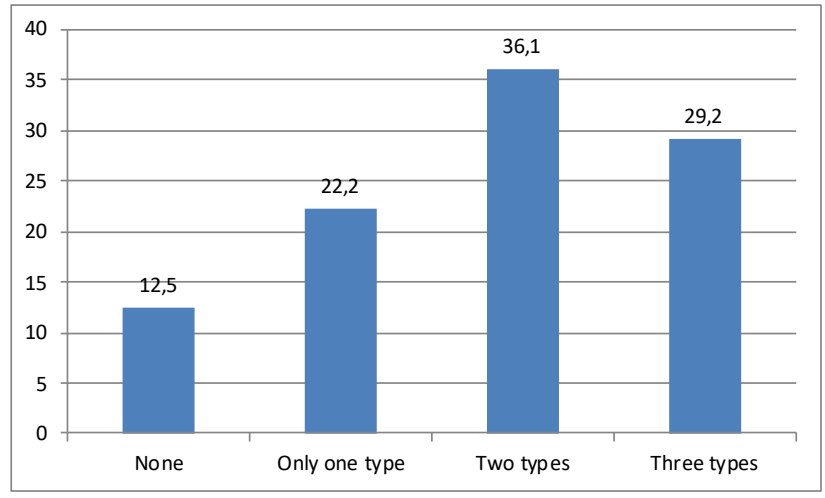

Figure 6. Non-Full member types of affiliation (\%). Note: Total $\mathrm{N}=68$ parties.

types of affiliation beside full membership offered by parties are represented by the "supporter" and "nonaffiliated participants" categories.

There is also a small group of parties, $12.5 \%$ of the sample, that seem to resist the current trend of providing alternatives to full membership. This raises the question of what factors influence the party's choice of different type of affiliations and the scope of affiliation modes they offer. In the next section of the article, we analyse the impact of two potential factors: party size and party family.

\subsection{Party Size}

We argue that party size relates to the variety of modes available to individuals to get involved with a political party and the rights and obligations attached to each of these different modes of affiliation. The relationship is expected to associate smaller parties with greater opportunities for non-membership participation. Table 3 partially supports our expectation that smaller parties are characterized by a higher degree of involvement of non-members, reinforcing claims by Tan (1998) and Weldon (2006). Almost 53\% of the selected parties classified as small provide two types of additional forms of affiliation beyond full membership, and 19\% even allow three more modes of affiliations they are also the smallest group of parties offering no other form of affiliation. Nevertheless, as shown in Table 3, there is a high share of large parties (34.5\%) offering three types of additional forms of affiliation, with the aim of extending their social reach beyond their own traditional classe gardée. Alternatively, due to the generalized low membership rates, such parties may as well actually only get to keep their classe gardée also with new recruitment measures. This challenges findings of previous studies on small 
Table 3. Non-members types of affiliation per party size (\%).

\begin{tabular}{lcccc}
\hline & \multicolumn{4}{c}{ Non-Full member types of affiliation } \\
\cline { 2 - 5 } & None & 1 type & 2 types & 3 types \\
\hline Small party & 4.8 & 23.8 & 52.4 & 19 \\
Medium-size party & 18.2 & 18.2 & 31.8 & 31.8 \\
Large party & 13.8 & 24.1 & 27.6 & 34.5 \\
Total & 12.5 & 22.2 & 36.1 & 29.2 \\
\hline
\end{tabular}

Note: Total $\mathrm{N}=68$ parties.

parties, and at the same time reinforces claims by Scarrow (2000).

To further explore our expectations, we run a correlation matrix outlining the association between the party size and other variables such as the types of affiliation and the degree of involvement of non-members within parties (Table 4). In line with our theoretical expectations, there is a moderate and negative association between the party size and the extent of non-membership participation opportunities (Tan 1998; Weldon 2006). As we move from small party to medium-sized to large party sizes, the provision of different forms for non-membership participation decreases. Thus, party sizes seem to be associated with the number and types of party affiliations available.

We also find two statistically significant relationships in the matrix where we can reject $\mathrm{H}_{0}$. Firstly, we find a positive and significant correlation between the degree of organizational permeability of the party and the obligations of full members. This supports the argument that parties that are more open reach out to nonmembers to strengthen their legitimacy and electoral support (Faucher 2015; Scarrow 2015; Garland 2016) but are also rooted in a highly disciplined, well organized and highly loyal membership base. Organizational permeability is combined with a strong and tightly regulated organizational role for full members.
Second, we find a positive and significant strong correlation between the number of non-full membership types of affiliation and the extent of the involvement of non-members. Thus, when parties offer a broad range of non-full membership types of affiliation, they also usually give non-enrolled members a varied choice of instruments for getting involved in the party and different channels for influencing intra-party decision-making. We also find a positive but not significant correlation between the indexes measuring membership rights and membership obligations (Table 4). Thus, the more rights members have, the more obligations they also have. This shows that party structures entailing broad roles for their grassroots members also require in return a high degree of loyalty (in the sense of willingness to remain involved even though this entails several obligations) and involvement from them.

\subsection{Party Family}

We argue that the party family relates to the variety of modes available for individuals to get involved with a political party and the rights and obligations attached to each of these different modes of affiliation (Kitschelt 2000). The direction of causality is the following: we expect that those parties belonging to social-democratic and leftist families, traditionally more open to internal democratization, will be characterized by a higher degree of involvement of non-members (Bolleyer 2007). In order to explore this link more systematically, we ran a correlation matrix exploring the link between party family and our dependent variables (table 5). It clearly shows a positive and significant association between non-member participation and party family (leftist parties are $\operatorname{coded}=1$, non-leftist parties $=0$ ). It also shows a positive link between party family and types of nonmember affiliation within parties. When moving from non-left parties to leftist ones, the degree of involve-

Table 4. Correlation matrix: party size.

\begin{tabular}{|c|c|c|c|c|c|}
\hline & $\begin{array}{l}\text { Organizational } \\
\text { permeability }\end{array}$ & Membership rights & $\begin{array}{l}\text { Membership } \\
\text { obligations }\end{array}$ & $\begin{array}{l}\text { Non-member } \\
\text { participation }\end{array}$ & $\begin{array}{l}\text { Non-Full member } \\
\text { types of affiliation }\end{array}$ \\
\hline Organizational permeability & 1 & & & & \\
\hline Membership rights & -.101 & 1 & & & \\
\hline Membership obligations & $.285^{\star}$ & .216 & 1 & & \\
\hline Non-member participation & -.092 & .078 & -.172 & 1 & \\
\hline Non-Full member types of affiliation & -.185 & -.065 & -.331 & $.489^{*}$ & 1 \\
\hline Party size & .100 & -.078 & -.060 & $-.138^{\star}$ & -.009 \\
\hline
\end{tabular}

* Significant at the 0.05 level. ${ }^{* \star}$ Significant at the 0.01 level.

Note: Total $\mathrm{N}=68$ parties. 
Table 5. Correlation matrix: party family (left vs non-left parties).

\begin{tabular}{|c|c|c|c|c|c|}
\hline & $\begin{array}{c}\text { Party Family (left vs } \\
\text { non-left parties) }\end{array}$ & $\begin{array}{l}\text { Organizational } \\
\text { permeability }\end{array}$ & Membership rights & $\begin{array}{l}\text { Membership } \\
\text { obligations }\end{array}$ & $\begin{array}{c}\text { Non-member } \\
\text { participation }\end{array}$ \\
\hline Party Family (left vs non-left parties) & 1 & & & & \\
\hline Organizational permeability & -0.58 & 1 & & & \\
\hline Membership rights & .196 & -.101 & 1 & & \\
\hline Membership obligations & -.043 & $.285^{\star}$ & .216 & 1 & \\
\hline Non-member participation & $.495^{\star *}$ & -.092 & .078 & -.172 & 1 \\
\hline Non-Full member types of affiliation & .132 & .139 & -.065 & $-.331^{\star *}$ & $.489^{\star *}$ \\
\hline
\end{tabular}

* Significant at the 0.05 level. ${ }^{*}$ Significant at the 0.01 level.

Note: Total $\mathrm{N}=68$ parties.

ment and the possibilities that are provided to non-full members in the party increase (supporting findings by Duverger 1954; Kitschelt 2000) $)^{13}$.

Further, a positive and significant association emerges between the degree of organizational permeability of the party and the obligations that full members have to perform (table 5) and a significant negative association emerges between membership obligations and the variation in types of non-full members' affiliation. Moreover, we can see an expected positive, significant and strong association between the scope of non-member involvement in party activities and the number of non-full membership types of affiliation. The other correlations we observe in table 5 are similar to those observed in the correlation matrix concerning party sizes. Firstly, the more rights are given to members, the broader the obligations for full members (but the association is not significant). Secondly, parties allowing several non-full member types of affiliation will also give these affiliates a broader scope of rights and instruments for getting involved within the party (and the correlation is significant)

We explored our expectations by splitting the sample into two the groups of left and non-left parties. The next section unpacks this further by looking in more details at the differences in organizational permeability, rights and obligations of members and non-members across the nine party families (1-9 scale, from far left/ communists $=1$ to populist radical right $=9^{14}$ ) identified by Krouwel's seminal work (2012: 363).

The explorative scatterplot below clearly outlines this relationship. When moving from the left to right of the spectrum of party family, and thus from left to nonleft parties, the degree of non-members' involvement in party activities clearly decreases (figure 7).

\footnotetext{
${ }^{13}$ It is worth noting that large-scale change in party regulations occurs very slowly, so even if the data have been collected in 2014-2015 the validity of the data is guaranteed.

${ }^{14}$ Greens/environmental parties are recoded as $=2$ on the scale.
}

If we look more in detail at each party family (table 6 ,) we can see a complex relationship between party family and organizational permeability.

Organizational permeability is relatively high in most parties regardless of the party family they belong to (table 6). However, in order to join the majority of Communist/far left parties, Social-democratic parties, Christian-democratic parties and far right parties, prospective full-members must satisfy a comprehensive list of criteria. The entry barriers seem to be particularly high in ethnic regionalist parties, parties of the mainstream left, rightist parties and particularly Christiandemocratic ones. Interestingly, conservative parties and far left/Communist parties are split equally between the two groups. New left/socialist parties provide the highest share of cases with low entry barriers, followed by environmental parties and liberal ones. The Social- and Christian-democratic parties have the lowest share of

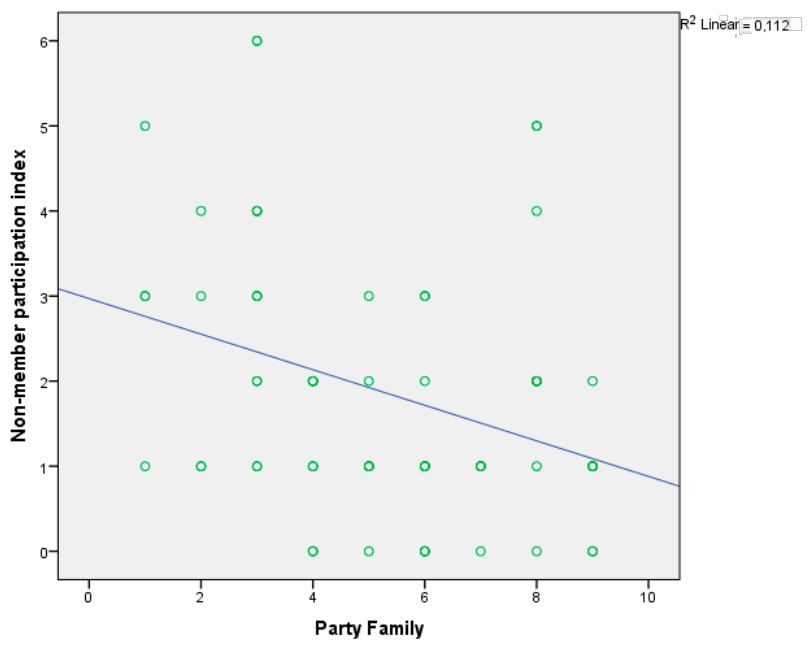

Figure 7. Party family and non-member participation (scatterplot with OLS line and confidence intervals). Note: Total $\mathrm{N}=68$ parties. 
Table 6. Organizational permeability by party family (\%).

\begin{tabular}{lcc}
\hline & $\begin{array}{c}\text { High Organizational } \\
\text { permeability } \\
\text { (low entry barriers) }\end{array}$ & $\begin{array}{c}\text { Low Organizational } \\
\text { permeability } \\
\text { (high entry barriers) }\end{array}$ \\
\hline Communist/far left & 50 & 50 \\
Enviromental & 55.6 & 44.4 \\
Socialist/new left & 66.7 & 33.3 \\
Social Democats & 33.3 & 66.7 \\
Christian Democrats & 14.3 & 85.7 \\
Liberal & 42.9 & 57.1 \\
Conservative & 50 & 50 \\
Ethnic Regionalist & 20 & 80 \\
Populist radical right & 37.5 & 62.5 \\
Total & 40 & 60 \\
\hline
\end{tabular}

Note: Total $\mathrm{N}=68$ parties.

Table 7. Non-members participation by party family (\%).

\begin{tabular}{lcc}
\hline & $\begin{array}{c}\text { Low Involvement of } \\
\text { Non-members }\end{array}$ & $\begin{array}{c}\text { High Involvement of } \\
\text { Non-members }\end{array}$ \\
\hline Communist/far left & 75 & 25 \\
Enviromental & 66.7 & 33.3 \\
Socialist/new left & 75 & 25 \\
Social Democats & 64.3 & 53.7 \\
Christian Democrats & 100 & - \\
Liberal & 100 & - \\
Conservative & 100 & - \\
Ethnic Regionalist & 100 & - \\
Populist radical right & 100 & - \\
Total & 85.9 & 14.1 \\
\hline
\end{tabular}

Note: Total $\mathrm{N}=68$ parties.

parties with high permeability, and the environmentalists are in a middle position. Thus, at first sight it seems that most parties erect substantial barriers to protect their full members regardless of party family.

Table 7 shows that, as expected, the parties on the left side of the party family spectrum provide the highest possibility for non-member participation. The score is particularly high among social democrats and environmental parties. Among all centre, centre-right to far right parties, the scores on the index for non-membership participation is very low or non-existent. Thus, this seems to support the idea that those parties belonging to social-democratic and leftist families, traditionally more open to internal democratization, will be characterized by a higher degree of involvement of non-members (Bolleyer 2007).

In addition, party families providing the highest possibility for non-members to participate corre-
Table 8. Rights and Obligations of members by party family (\%).

\begin{tabular}{lcccc}
\hline & $\begin{array}{c}\text { Membership rights } \\
\text { index }\end{array}$ & \multicolumn{2}{c}{$\begin{array}{c}\text { Membership } \\
\text { obligations index }\end{array}$} \\
\cline { 2 - 5 } & Low & High & Low & High \\
\hline Communist/far left & 75 & 25 & 25 & 75 \\
Enviromental & 33.3 & 66.7 & 55.6 & 44.4 \\
Socialist/new left & 25 & 75 & 25 & 75 \\
Social Democats & 85.7 & 14.3 & 64.3 & 35.7 \\
Christian Democrats & 71.4 & 28.6 & 37.5 & 62.5 \\
Liberal & 71.4 & 28,6 & 66.7 & 33.3 \\
Conservative & 92.3 & 7.7 & 46.2 & 53.8 \\
Ethnic Regionalist & 80 & 20 & 20 & 80 \\
Populist radical right & 50 & 50 & 75 & 25 \\
Total & 69.6 & 30.4 & 50.7 & 49.3 \\
\hline
\end{tabular}

Note: Total $\mathrm{N}=68$ parties.

spond to those with low organizational permeability such as mainstream and far left party families. This could imply that those parties having high entry barriers to protect their organization and activists from purely event-based members or "instant members" would also provide different means of participation for non-members. Within those parties, non-members can participate in a broad range of intra-party activities and take part in internal decision-making, but their status is clearly separated and distinct from the status and role of full members. For instance, in July 2016 the UK Labour NEC ruled that only those who have been members for more than six months will be allowed to vote in the leadership race, while new supporters will be given two days to sign up as registered supporters and to pay $£ 25$ to vote.

Table 8 shows that in most party membership obligations are high and are accompanied by low scores on the membership rights index. Again, it can be seen that new left parties and environmental parties are among the party families scoring highest in the membership rights index, and socialist/new left parties also require that their members follow a broad set of obligations. Overall, we can see that left (far, new and mainstream) and environmental parties have higher entry barriers but also allow for more possibilities for non-members to participate within the party. Furthermore, they compensate for this by providing full-members with substantial rights to influence the internal decision-making, particularly in the case of socialist and new left parties. This further supports the link between party family and the regulation of non-member rights of participation within the party highlighted by the above correlation matrix 


\section{DISCUSSION OF FINDINGS AND CONCLUSIONS}

In conclusion, we explore differences in parties' responses to recent societal challenges by allocating new rights and power to its members and non-members. We map the current landscape of rights, obligations and degree of involvement of non-members and we also explore potential factors underlying the variation across parties. The empirical analyses show only a limited support for our first expectation. There seems to be an association between party organizational size (measured by membership size) and the use of non-formalized forms of adhering to a political party. However, no statistically significant association emerges between the regulation of participatory rights for non-members and party organizational sizes. Our results support claims that large parties tend to give more rights to their enrolled members, while smaller parties are more likely to be organizationally open and allocate more rights to non-members (Faucher 2015; Scarrow 2015; Garland 2016).

Conversely, there seems to be some empirical support for our second expectation, linking party family with the provision and regulation of non-member participation opportunities and rights. The analysis supports our explorative expectations that parties on the left and environmental parties provide more space for the participation of non-members (Duverger 1954; Kitschelt 2000; Bolleyer 2007). The correlation matrix confirms this association. These two party families are also characterized by high barriers to entry for new full members and substantial full-membership rights. Within right wing and conservative party families, we do not observe a uniform pattern in the distribution of full-party members' rights and obligations or in the level of permeability. However, most right wing and conservative parties allow very limited forms of non-membership participation within their organizational structures. This seems to imply that the regulations regarding full- and nonmembership rights and obligations are (at least up to now) more differentiated based on party family effects rather than because of organizational imperatives to increase competiveness.

This research has important theoretical, empirical and normative repercussions. Our main theoretical contribution relates to the scholarly debate on the tradeoff between openness and the organizational viability of parties (Katz and Mair 2009; Cross and Katz 2013; Ignazi 2020). Our findings show how different parties in terms of family and size - offer different participatory channels to non-members, but the relationship between organizational openness and party type is more fluid and complex than theorized by previous literature. We thus challenge the distinction often found in the literature between parties as either membership organization or a loose "collection of voters" (Scarrow et al. 2017; Faucher 2015). Our findings also challenge the debate on parties as "empty vessels" (Katz and Kolodny 1994). If members are not important, why create non-members possibilities to participate at all? Parties see both full members and non-members as key actors for supplying vital resources and communication during elections. In addition, we show that full members maintain the main rights and remain the central decision-makers in many areas, which goes against the cartel party thesis (Katz and Mair 2009).

In empirical terms, we provide new comparative data on parties' societal reach and linkage function in advanced democracies. At a normative level, our research shows that parties need to strike a balance between members' and non-members' rights in order to strengthen their societal linkages, representation capacity and legitimacy, but at the same time use new forms of affiliation as a recruitment mechanism, to secure long term, loyal members. Parties need to maintain a clear line of distinction between the two groups but also to provide specific incentives for non-members in terms of rights and influence gained so that they may be willing to take up the costs of becoming full members.

Most importantly, the most interesting finding of this mainly descriptive exercise is that some of the parties, which maximize formal participation opportunities for non-members, are also those that make it most difficult to join as a full member. It makes sense that parties might come up with a better deal for supporters if obtaining membership is seen as too arduous; on the other hand, if this better deal is too attractive, that might further erode the attraction of party membership. Yet parties that maintain high barriers to membership while reducing barriers to supportership do not seem to be concerned about this possible trade-off. This entails relevant implications for the ability of parties to secure and strengthen their social linkage role. In fact, our findings suggest that keeping a double-track process for getting involved in the party might be counterproductive for the political economy of party survival (both electoral and organizational). However, it ensures that a potentially higher number of individual citizens could be convinced to become involved in politics even if in a less formal and continuous way.

Future research might thus focus on this point and possibly investigate further to see whether membership has been stable or growing in parties with above average supportership opportunities. A second new avenue of research based on new data and findings is not only to 
explore the scope of rights granted to members and nonmembers, but also their nature. Specifically, the analysis of the difference between rights related to the party as organization or as electoral actor could shine further light on the balance of power between the party on the ground, in central and public office. In short, the challenge faced by parties of how to achieve more societal linkage without risk to the organization needs to be explored further.

\section{BIBLIOGRAPHICAL REFERENCES}

Aylott, N., \& Bolin, N. (2017). Managed intra-party democracy: Precursory delegation and party leader selection. Party Politics 23(1): 55-65.

Bolin, N., Aylott, N., von dem Berge, B., \& Poguntke, T. (2017). Patterns of intra-party democracy across the world. In: Organizing Political Parties: Representation, Participation, and Power / [ed] Susan E. Scarrow, Paul D. Webb and Thomas Poguntke, Oxford: Oxford University Press, 2017, pp. 158-184

Bolleyer, N.. (2007). Small Parties - from Party Pledges to Government Policy. West European Politics 1(30): 121-147.

Bolleyer, N., \& Correa, P. (2020). Member Influence and Involvement in Civil Society Organizations: A Resource Dependency Perspective on Groups and Parties. Political Studies, Online First: 0032321720968018.

Cross, W. P. \& Katz. R. (2013). The challenges of intra-party democracy. Oxford: Oxford University Press.

Dalton, R. \& Wattenberg M.P. (2000). Parties without partisans : political change in advanced industrial democracies. Oxford ; New York: Oxford University Press.

Dommett, K. (2020). The reimagined party: Democracy, change and the public. In The reimagined party. Manchester University Press.

Faucher, F. (2015). New forms of political participation. Changing demands or changing opportunities to participate in political parties. Comparative European Politics 13(4): 405-429.

Fisher, J.; Fieldhouse E. \& Cutts E. (2014). Members Are Not the Only Fruit: Volunteer Activity in British Political Parties at the 2010 General Election. The British Journal of Politics \& International Relations, 16(1): 75-95.

Garland, J. (2016). A wider range of friends: Multi-speed organising during the 2015 Labour leadership contest. The Political Quarterly 87(1): 23-30.

Gauja, A. (2014). The construction of party membership, European Journal of Political Research, doi:10.1111/1475-6765.12078.
Gerbaudo, P (2019) The Digital Party: Political Organisation and Online Democracy. London: Pluto Press.

Gibson, R; 1 Harmel R. (1998). Party Families and Democratic Performance: Extraparliamentary vs. Parliamentary Group Power. Political Studies 46(3): 633-650.

Gomez, R., \& Ramiro, L. (2019). The limits of organizational innovation and multi-speed membership: Podemos and its new forms of party membership. Party Politics 25(4): 534-546.

Hooghe, M., \& Kölln, A. K. (2020). Types of party affiliation and the multi-speed party: What kind of party support is functionally equivalent to party membership?. Party Politics 26(4): 355-365.

Ignazi, P. (2020). The four knights of intra-party democracy: A rescue for party delegitimation. Party Politics 26(1): 9-20.

Katz, R. \& Mair P. (2009).The Cartel Party Thesis: A Restatement. Perspectives on Politics 7(4): 753-766.

Katz, R. \& Kolodny R. (1994). Party Organization as an Empty Vessel: Part ies in American Politics. In How Parties Organize: Change and Adaptation in Party Organizations in Western Democracies Eds. Katz, Richard S. and Peter Mair. London: Sage Publications, pp. 23-50.

Kitschelt, H. (2000). Linkages between Citizens and Politicians in Democratic Polities. Comparative Political Studies 33(6-7): 845-879.

Kernell, G. (2015). Party Nomination Rules and Campaign Participation. Comparative Political Studies 48(13): 1814-1843.

Kölln, A. K. (2016). Party membership in Europe: Testing party-level explanations of decline. Party Politics 22(4): 465-477.

Kosiara-Pedersen, K., Scarrow S. \& Van Haute E. (2017). Rules of engagement? Party membership costs, new forms of party affiliation, and partisan participation, In: Susan S. Scarrow, Paul D. Webb, Thomas Poguntke (eds.) Organizing Political Parties Representation, Participation, and Power, Oxford: Oxford University Press.

Krouwel, A. (2012). Party transformations in European democracies. SUNY Press.

Mair, P. (2013). Ruling the void: The hollowing of Western democracy. Verso Books.

Michels, R. ([1911] 1962). Political Parties: A Sociological Study of the Oligarchical Tendencies of Modern Democracy. New York: Hearst's International Library Co.

Mjelde, H. L. (2015). Non-Member Participation in Political Parties: A Framework for Analysis and Selected Empirical Examples from Scandinavia. Representation 51(3): 299-310. 
Pettitt, R. T. (2014). Contemporary party politics. Palgrave Macmillan.

Pilet, J-B. \& Cross, W. (eds) (2015). The Politics of Party Leadership: A Cross-National Perspective. Oxford: OUP.

Pizzimenti, E., Calossi, E. \& Cicchi, L. (2020) Removing the intermediaries? Patterns of intra-party organizational change in Europe (1970-2010). Acta Politica, online first: https://doi.org/10.1057/s41269-020-00180-6

Poguntke T.; Scarrow S.; Webb, P. (2020). "PPDB_ Round1a_1b_consolidated_v1", https://doi. org/10.7910/DVN/NBWDFZ, Harvard Dataverse, V1.

Poguntke, T, Scarrow, S, Webb, P, et al. (2016) Party Rules, Party Resources and the Politics of Parliamentary Democracies: How Parties Organize in the 21st Century. Party Politics 22(6): 661-678.

Sandri G.; Seddone A. \& Venturino F. (eds) 2015. Party Primaries in Comparative Perspective, London: Routledge.

Scarrow, S. (1996). Parties and their members : organizing for victory in Britain and Germany. New York: Oxford University Press.

Scarrow, S. (2000). Parties without members? Party organisation in a changing electoral environment. In Parties without partisans. Political change in advanced industrial democracies, eds. Russell J. Dalton and Martin P. Wattenberg. Oxford: Oxford University Press.

Scarrow, S. (2015). Beyond Party Members: Changing Approaches to Partisan Mobilization, Oxford, Oxford University Press.

Scarrow, S. E. (2018). Political finance regulation and equality: comparing strategies and impact. In Handbook of Political Party Funding. Edward Elgar Publishing.

Scarrow, S. E. (2020). Intra-Party Democracy and Party Unity: Varied Rules, Varied Consequences. Representation, 1-17.

Scarrow, S. E., Webb, P. D., \& Poguntke, T. (Eds.). (2017). Organizing political parties: Representation, participation, and power. Oxford University Press.

Tan, A. C. 1998. The impacts of party membership size: A cross-national analysis. The Journal of Politics 60(1): 188-198.

Van Biezen, I., Mair, P., \& Poguntke, T. (2012). Going, going,... gone? The decline of party membership in contemporary Europe. European journal of political research 51(1): 24-56.

Van Haute E., Gauja, A. (eds.) 2015. Party membership and activism, London, Routledge.

Van Haute E. (2016). The management of party affiliation: an organisational perspective. Paper presented at the ECPR General Conference, Prague, 7-10 September 2016.

Von dem Berge, B., \& Poguntke, T. (2017). Conceptualization and Index Construction. Organizing political parties: Representation, participation, and power, 136.

von Nostitz, F. C., \& Sandri, G. (2018). State funding and party primaries. In Handbook of Political Party Funding. Edward Elgar Publishing.

Webb, P.l, Poletti, M. \& Bale, T. (2017). So who really does the donkey work in 'multi-speed membership parties'? Comparing the election campaign activity of party members and party supporters. Electoral Studies 46: 64-74.

Weldon, S. (2006). Downsize my polity? The impact of size on party membership and member activism. Party Politics 12(4): 467-481. 
APPENDIX A

Table A1. Cases included in the database.

\begin{tabular}{|c|c|c|c|c|c|c|c|}
\hline Country & Party & $\begin{array}{c}\text { Year of } \\
\text { adoption of } \\
\text { statutes }\end{array}$ & $\begin{array}{c}\text { Year of Party } \\
\text { Website } \\
\text { analysed }\end{array}$ & Country & Party & $\begin{array}{c}\text { Year of } \\
\text { adoption of } \\
\text { statutes }\end{array}$ & $\begin{array}{c}\text { Year of Party } \\
\text { Website } \\
\text { analysed }\end{array}$ \\
\hline \multirow{4}{*}{ Australia } & National Party of Australia & 2013 & \multirow{4}{*}{$\begin{array}{c}2014 \text { for all } \\
\text { parties }\end{array}$} & \multirow{4}{*}{ Portugal } & $\mathrm{BE}$ & 2012 & \\
\hline & Australian Labor Party & 2014 & & & PS & 2012 & \\
\hline & Liberal Party of Australia & 2009 & & & PSD & 2011 & \\
\hline & Australian Greens & 2014 & & & CDS-PP & 2014 & \\
\hline \multirow{7}{*}{ Austria } & Pirate Party Australia & 2014 & & \multirow{4}{*}{ Spain } & IU & 2012 & \\
\hline & SPÖ & 2012 & & & PSOE & 2012 & \\
\hline & ÖVP & 2007 & & & $\mathrm{PP}$ & 2012 & \\
\hline & FPÖ & 2001 & & & Podemos & 2014 & \\
\hline & Grüne & 2012 & & \multirow{9}{*}{$\begin{array}{l}\text { United } \\
\text { Kingdom }\end{array}$} & SVP/UDC & 2008 & \\
\hline & BZÖ & 2005 & & & SPS/PSS & 2012 & \\
\hline & MR & 2005 & & & FDP.The Liberals & 2009 & \\
\hline \multirow{6}{*}{ Belgium } & PS & 2013 & & & $\mathrm{CVP} / \mathrm{PDC}$ & 2008 & \\
\hline & Ecolo & 2013 & & & $\mathrm{BDP} / \mathrm{PBD}$ & 2912 & \\
\hline & $\mathrm{CDH}$ & 2002 & & & Labour & 2013 & \\
\hline & SPA & 2002 & & & Conservatives & 2009 & \\
\hline & GROEN & 2011 & & & Liberal Democrats & 2013 & \\
\hline & $\mathrm{CD} \& \mathrm{~V}$ & 2009 & & & UKIP & 2014 & \\
\hline
\end{tabular}

\begin{tabular}{|c|c|c|}
\hline & & \\
\hline & UMP & 2012 \\
\hline France & Front de Gauche & 2013 \\
\hline & EELV & 2013 \\
\hline & FN & 2011 \\
\hline & $\mathrm{CDU}$ & 2012 \\
\hline & CSU & 2014 \\
\hline & SPD & 2014 \\
\hline Germany & Greens & 2014 \\
\hline & Left & 2014 \\
\hline & AfD & 2014 \\
\hline & Pirate & 2014 \\
\hline & Fine Gael & 2011 \\
\hline Ireland & Labour Party & 2013 \\
\hline & Fianna Fail & 2013 \\
\hline & $\mathrm{PD}$ & 2012 \\
\hline & SEL & 2012 \\
\hline & M5S & 2009 \\
\hline Italy & UDC & 2007 \\
\hline & PDL & 2011 \\
\hline & NCD & 2014 \\
\hline & $\mathrm{LN}$ & 2014 \\
\hline & National Party & 2013 \\
\hline & Labour Party & 2014 \\
\hline New Zealand & Green Party & 2012 \\
\hline & New Zealand First & 2013 \\
\hline
\end{tabular}

Conservative Party 2013

New Democratic Party 2013

Canada Liberal Party of Canada 2014

Bloc Québécois 2014

Green Party 2013

PS 2012

\begin{tabular}{|c|c|c|}
\hline \multirow{5}{*}{ France } & & \\
\hline & UMP & 2012 \\
\hline & Front de Gauche & 2013 \\
\hline & EELV & 2013 \\
\hline & $\mathrm{FN}$ & 2011 \\
\hline \multirow{7}{*}{ Germany } & $\mathrm{CDU}$ & 2012 \\
\hline & CSU & 2014 \\
\hline & SPD & 2014 \\
\hline & Greens & 2014 \\
\hline & Left & 2014 \\
\hline & AfD & 2014 \\
\hline & Pirate & 2014 \\
\hline \multirow{3}{*}{ Ireland } & Fine Gael & 2011 \\
\hline & Labour Party & 2013 \\
\hline & Fianna Fail & 2013 \\
\hline \multirow{7}{*}{ Italy } & PD & 2012 \\
\hline & SEL & 2012 \\
\hline & M5S & 2009 \\
\hline & UDC & 2007 \\
\hline & PDL & 2011 \\
\hline & NCD & 2014 \\
\hline & $\mathrm{LN}$ & 2014 \\
\hline \multirow{4}{*}{ New Zealand } & National Party & 2013 \\
\hline & Labour Party & 2014 \\
\hline & Green Party & 2012 \\
\hline & New Zealand First & 2013 \\
\hline
\end{tabular}

